American Journal of Biological and Environmental Statistics
2017;3(1): 1-4
http://www.sciencepublishinggroup.com/j/ajbes
doi: $10.11648 /$ j.ajbes.20170301.11
ISSN: $2471-9765$ (Print); ISSN: $2471-979 X$ (Online)

\title{
Threats, Use and Management Interventions for Restoration of Lake Chitu West Arsi, Ethiopia
}

\author{
Girum Faris ${ }^{1, *}$, Genene Tefera ${ }^{2}$ \\ ${ }^{1}$ Access and Benefit Sharing Directorate, Ethiopian Biodiversity Institute, Addis Ababa, Ethiopia \\ ${ }^{2}$ Microbial Biodiversity Directorate, Ethiopian Biodiversity Institute, Addis Ababa, Ethiopia
}

Email address:

girumf@gmail.com (G. Fari), girumf@ibc.gov.et (G. Fari)

${ }^{*}$ Corresponding author

\section{To cite this article:}

Girum Faris, Genene Tefera. Threats, Use and Management Interventions for Restoration of Lake Chitu West Arsi, Ethiopia, American Journal of Biological and Environmental Statistics. Vol. 3, No. 1, 2017, pp. 1-4. doi: 10.11648/j.ajbes.20170301.11

Received: November 26, 2016; Accepted: December 6, 2016; Published: February 9, 2017

\begin{abstract}
Lake Chitu is one of Ethiopian Flamingo Lakes known by single dominant blue green algal specie called Arthrospira fusiformis. A household questionnaire survey of respondents, key informants and focus group discussion were made in 2012 in Labu Subuqa kebele where lake Chitu is found to see major threats for general ecosystem disturbance, to see the use of the lake for the surrounding community and to identify major stakeholders for restoration and conservation of the lake in an integrated way. Results showed that deforestation of the catchment area is the main threat for the total degradation of the lake. Soil erosion occurred due to intensive loss of vegetation that increased the amount of silt in the lake. Deposition of animal debris and detergents are added to the lake because of human and cattle direct contact. The timely decrease in the size might be due to siltation. The community is using the lake only for washing clothes because of its alkalinity and soap nature. They also take bath on the hot spring that immediately comes from the edge of the lake that would eventually contaminate and change the nature of the lake. This study revealed that the community is not using the lake water only for the purpose of sanitation. Several stakeholders have been identified, consulted and participated on restoration of the lake biodiversity.
\end{abstract}

Keywords: Threats, Management Interventions, Restoration, Stakeholders, Cyanobacteria

\section{Introduction}

Flamingo Lakes are part of a chain of lakes found on the floor of the eastern arm of the Great Rift Valley of Africa [9]. Flamingo lakes often harbor many unique species, adapted to high alkalic and high salinity conditions [12]. Cyanobacteria are mostly observed dominantly in Flamingo Lakes. The most abundant blue-green alga is Spirulina /Arthospira fusiformis/ which is responsible for giving the Flamingo Lakes their characteristic greenish color [7], [3]. Alkaline saline lakes have tremendous potential as a source of harvestable and cultivable algal resources (e.g. Spirulina/Arthrospira) and unique thermophilic microbial communities [8].

The Ethiopian Rift Valley Lakes are alkaline where the $\mathrm{pH}$ value ranges from 9 to more than 10, and sodium and sodium bicarbonate compounds are in high concentration [11]. Lake Chitu is one of the Ethiopian Rift Valley Flamingo Lakes formed due to volcanic explosion. It is one of the most saline lakes with single dominant species of algae [1]. In Lake Chitu Arthrospira fusiformis is a strongly dominant species usually found forming dense blooms. The lake harbors thousands of Flamingos and is characterized by high $\mathrm{pH}$, high salinity and high alkalinity. [5], [2]. Very few organisms would be expected to survive in it, and yet there are organisms, especially cyanobacteria and microalgae, that have evolved to occupy these environments [7].

Spirulina are multi cellular and filamentous blue - green alga that has gained considerable popularity in the health food industry and increasingly as a protein and vitamin supplement to aquaculture diets [4], [6]. Spirulina recommended as a suitable protein source to combat malnutrition and protein deficiency in developing countries [6]. The biodiversity of the lake is threatened by both natural 
and anthropogenic activities. Climatic change has accelerated water stress in the lake catchment [10]. The study examines major use value of the lake, threats for ecosystem changes and role of key stakeholders for integrated biodiversity in situ conservation. The Specific Objectives were (a) to identify use of the lake for the surrounding community. (b) to evaluate some factors affecting the ecosystem of the lake. (c) to identify major stakeholders towards conservation of the lake and its biodiversity (d) to forward major interventions for sustainable conservation of the lake.

\section{Materials and Methods}

\subsection{Study Area}

Lake Chitu is one of volcanic explosion crater lakes of Ethiopian Rift Valley which is located at South of Addis Ababa in West Arsi zone Aje district of Labu Subuqa kebele. The lake is situated at $25 \mathrm{~km}$ from Shashamane town with latitude $07^{\circ} 24^{\prime} 26^{\prime \prime} \mathrm{N}$, longitude of $038^{\circ} 25^{\prime} 33^{\prime \prime} \mathrm{E}$ and an altitude of 1540 meters above sea level. The lake has an area of $0.8 \mathrm{~km}^{2}$ and a maximum depth of $21 \mathrm{~m}$.

\subsection{Data Collection Methods}

Random sampling method by taking each village as a cluster was employed. There are 12 villages in the in the kebele accordingly 10 household heads from each village (120) respondents were taken randomly and interviewed. Three elders were deliberately selected from each village as key informants and focus group discussions bringinging the total number of key informants 36 , this helps to get reliable information.

\subsection{Primary and Secondary Data Collection Methods}

Primary data were generated through personal interview from all 120 respondents based on semi structured questionnaires (both closed and open questions), The key informant interview technique was employed by interviewing those 36 elders chosen from each village. After these steps all the elders come together and asked similar questions as focused group discussion. The group discussions were conducted as a follow-up to the content analysis and individual interactions in interviews.

During this study secondary information was collected from relevant offices and publications and compiled with primary data to make the provided information more inclusive. All the necessary data was taken from woreda and kebele bureau of agriculture and administration.

\subsection{Data Analysis}

The data generated from questionnaire survey about the lake was analyzed using Statistical Package for Social Sciences (SPSS 17). Descriptive statistics and percentages were used to present the results. Some of the survey questions allowed the respondents to give more than one response allowing them to give all possible responses.

\section{Results}

\subsection{Demographic Data}

Based on the data obtained from kebele administration during the study, the total population of the kebele is 4273 . Seven hundred four household heads were registered in the kebele, of which $634(90 \%)$ are male household heads \&170 $(10 \%)$ are female household heads. In Ethiopia it is common to find rural households headed by men, if not the female household heads are widows or divorcées.

Table 1. Social structure of Lebu Subuqa kebele.

\begin{tabular}{ll}
\hline Social Structure & No. \\
\hline Male household heads & 534 \\
Female household heads & 170 \\
\hline Total number of house holds & 704 \\
\hline
\end{tabular}

Source: woreda administration office.

The age of the studied households ranges from 30 to 91 years. Of the entire study subject, $17(13.7 \%)$ were below 30 , $31(25.6 \%)$ were between 30-45 years, $30(24.7 \%)$ were between the age 45-60years and 42 (35.8) respondents were above 60 .

\subsection{Duration and Knowledge of Respondents}

People who live in a certain area for a longer period of time accumulate much experience and knowledge. Fortunately, $72(60 \%)$ of the respondents have more than 45 years of residence in the study area. This indicates that the respondents are knowledgeable enough about their area to provide useful information. The remaining respondents had less than 45 years of residency in the kebele.

\subsection{Livelihood Activities}

Agriculture is the major livelihood activity of people living around Chitu lake. Mixed agriculture is the major economic practice for the lake community in which most of the respondents rely on it, $87(72.5 \%)$. The contribution of livestock in supporting the livelihood of lake community is paramount. It is a back bone for agricultural activities, sustaining protein source for the family and income generation. The remaining thirty-three $(27.5 \%)$ rely on crop production.

\subsection{Source of Drinking Water}

Most of the respondents $76(63.3 \%)$ answered that they use tap water for their drinking. On the other hand, 44 (36.7\%) respondents who are residing near the catchments of the lake use the spring water as their source of drinking water that is coming from the immediate mouth of the lake and use it after cooling, this might have a great role in contaminating the lake. They did this as they had no alternative, since ta station is very far from their residence area.

\subsection{Use of Lake Water for the Community}

Most of the respondents $76(63.3 \%)$ replied that they use 
the lake water for nothing, but those who very far from tap water station $44(36.7 \%)$ use lake water only for the purpose of sanitation. They wash their clothes on the shore of the lake because of its soap nature. They also take bath at the edge of the lake using spring water that would eventually change the nature of the lake. From this responses we can understand that that the decrease in size of the lake from time to time has no connection with the use of the lake. The community never used the lake water for the purpose of irrigation so far.

\subsection{Economic Activities Around the Lake}

The major economic activity around the lake the lake is rarely visited by tourists and researchers. This is due to its peculiar feature in the Rift Valley and harboring thousands of flamingo birds.

\subsection{Major Threats of the Lake}

Deforestation of vegetation from catchment area is the main threat for the disturbance the lake ecosystem. According to informants, the lake was surrounded by natural forest which was unique in its species composition. Participants recalled that wood and non-wood products for household consumption and income generation were extracted from the forest, since the establishment of villages. However, excessive cutting of trees was traced back over a short period of time, especially during the transition periods, and it has contributed a lot to the depletion of the forest. Deforestation has also been resulted in destruction of the total biodiversity of the lake and its catchment which lead to local extinction of several flamingos, seasonal immigrating birds and other wild animals.

Based on the information obtained, soil erosion is another major threat for the disturbance of the lake ecosystem. There is a decrease in water volume from time to time because of siltation. As a result of deposition of animal and plant debris and sediment loading several springs become nonfunctional. This phenomenon could contribute a lot for the decrease in volume of from time to time. Addition of detergents and toxic substances would eventually change the chemistry of lake. As a result, drastic water quality changes could occur unless the situation reversed.

\subsection{Stakeholders Identification to Ensure Sustainability of the Lake}

The major stakeholders identified for the restoration of the lake biodiversity were Ethiopian Biodiversity Institute and Ethiopian Wild Life Conservation Authority from Federal Government, Zonal administration office, Zonal Agricultural office, Woreda Administrations, Woreda Agricultural office, local NGO (ANCDA) and community were identified as the main responsible bodies for the restoration of biodiversity of the lake ecosystem.

\subsection{Majors Taken by Stakeholders}

Based on the findings of this study the identified stakeholders were contacted and agreed. After the consent was made among stakeholders, several workshops were conducted to design some rehabilitation measures with share of responsibilities. Awareness rising was made to the community level through full engagement of stakeholders. All stakeholders budget money and incorporated in to their annual work plan. Accordingly, more than 10,000 seedlings of indigenous tree species were planted on the lake catchments.

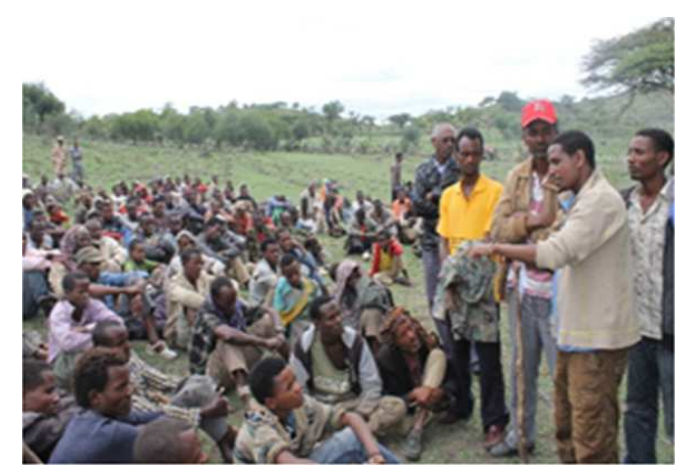

Fig. 1. Awareness sessions before plantation.

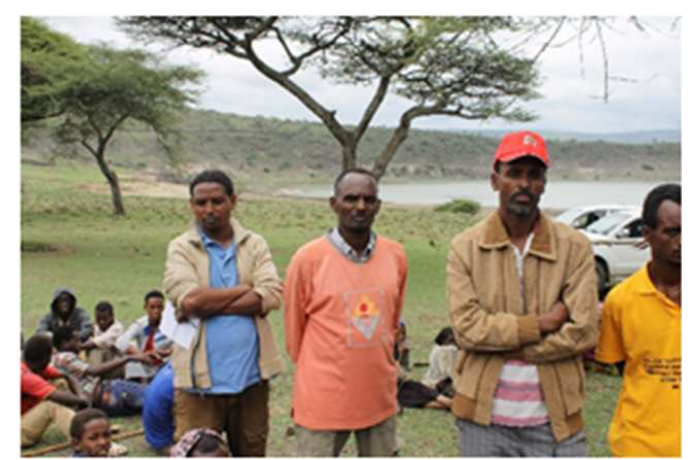

Fig. 2. Awareness sessions before plantation.

The government has given special attention towards the conservation of biodiversity and to minimize carbon emission to zero and for further green revolution development. This is the main input for restoration of natural resources. As a result, there is high demand for restoration of lake from local community, authorities and stakeholders. Ongoing natural resources conservation activities such as afforestation, watershed works led by the Ministry of Agriculture all over the country is a good opportunity for the restoration such degraded environments and similar settings.

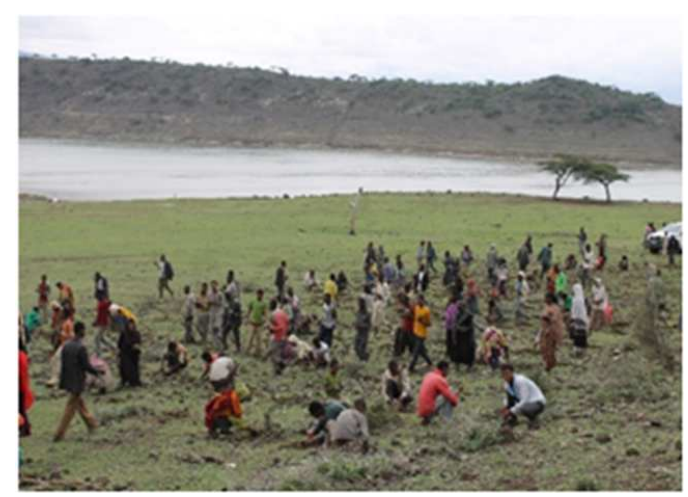

Fig. 3. Plantation of lake shore. 


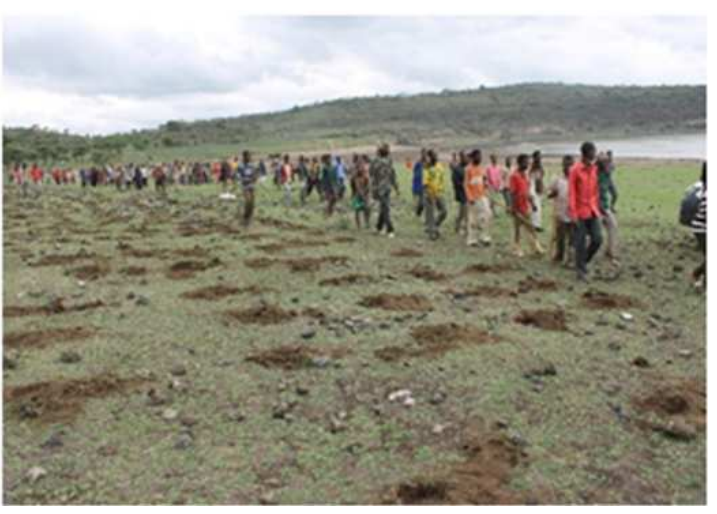

Fig. 4. Plantation of lake shore.

\subsection{The Way Forward for Sustainability of Lake}

Drilling of water for the community solves most of the problems complained by the respondents and focus group discussion participants. Therefore, all stakeholders must work for the sustainable water source of the community in order to save the lake. All respondents agreed that they are ready to incorporate the lake conservation strategy to their annual natural resource conservation program which is led by the government. They are also ready for planting trees and keeping from human and cattle interference. Vegetation cover will ensure moisture content and retain siltation formed by erosion; therefore, any meaningful vegetation coverage of eroded areas must be done for maintaining of the lake biodiversity. National Parks are a source of foreign revenue through tourism so increasing the protected status of the lake is mandatory. Regular evaluation and monitoring of such community based natural resource conservation is very crucial for sustainable developments. It is true that several achievements were announced from such community based restoration and conservation, so increasing the level of awareness of the community at all levels makes the conservation effort reliable.

\section{Conclusion}

Drastic change of the lake environment is due to deforestation of the catchment area. Excessive cutting of trees occurred during the previous two transitional periods of governments; as a result the total biodiversity of the lake is lost and highly affected. The main problem for the lake is siltation because of erosion. The community complained that due to shortage of agricultural land they left their animas on the catchment for grazing which contributes a lot for erosion and high deposition of silt in the lake. They did this as they have been no any alternative field for the pasture. Detergents and chemicals are added to the lake from different directions that would eventually distract the algal community.

The spring water that constantly flows to the lake is also adding detergents and waste materials to the lake which affect its chemical nature. The continued loss of biodiversity, unless urgently will be addressed, severely constrain the efforts of governments for development. The consequences of biodiversity loss and mismanagement as well as ecosystem disruption severely affect the communities. The progress towards development will only be possible in the future if biodiversity is preserved.

\section{Acknowledgements}

We acknowledge Ethiopian Biodiversity Institute for full filling all the necessary facilities for restoration of the lake. We also acknowledge all stakeholders, governmental bodies and the community.

\section{References}

[1] Desta, S., 1997. The present status of the Lesser Flamingo in Ethiopia. In. Howard, G. W. (Ed). Conservation of the Lesser Flamingo in Eastern Africa and Beyond. Proceedings of a workshop at Lake Bogoria, Kenya 26-29 August 1997 IUCN Eastern Africa Regional Programme. pp 40-46.

[2] Gebremariam, Z. and Taylor, W. D., 1997. Bacteriachlorophyll relationships in Ethiopian lakes of varying salinity: are soda lakes different? J. Plank. Res. 19: 647-654.

[3] Grant, W. D., W. E. Mwatha and B. J. Jones., 1990. Alkaliphiles: Ecology, Diversity and application. Federation of European Microbiological Societies (FEMS) Microbiological Reviews 75: 255-270.

[4] Habib, M. A. B.; Parvin, M.; Huntington, T. C.; Hasan, M. R. 2008. A review on culture, production and use of spirulina as food for humans and feeds for domestic animals and fish. FAO Fisheries and Aquaculture Circular. No.1034. Rome, FAO. $33 \mathrm{p}$.

[5] Kebede E., GebreMariam Z., and Ahlgren, I., 1994. The Ethiopian Rift Valley lakes: Chemical characteristics of a salinity-alkalinity series. Hydrobiologia. 288: 1-12.

[6] Kebede E., 1997. Response of Spirulina platensis (Arthrospira fusiformis) from Lake Chitu, Ethiopia, to salinity stress from sodium salts. J. Appl. Phycol. 9: 551-558.

[7] Matagi, S. V., 1996. The effect of pollution on a Ugandan stream. Ach. Hydrbiol. 137: 537-549.

[8] Mutangah, J. G., W. Mwatha, C. Kamau, O. Nasirwa and N. Gichuru., 2000. Biodiversity Status and Trends. Conservation and Sustainable use of Biodiversity in the Eastern Rift Valley Lakes. Rift Valley Lakes Project. Kenya KEN98G41/A/1G/99.

[9] Njuguna, S. 2000. Conservation and Sustainable use of Biodiversity in the Eastern Rift Valley Lakes. Analysis and Synthesis Paper. Rift Valley Lakes Project. GEF/UNDP/UNEP. Ethiopia ETH98G41/A/1G/99; Kenya KEN98G41/A/1G/99; Tanzania URT97G43/C/1G/99.

[10] Samuel. v., 2004. A biodiversity assessment of the flamingo lakes of eastern Africa, tropical conservancy biodiversity 5 (1).

[11] Talling, J. F., and Talling, I. B., 1965. The chemical composition of African lake waters. Int. Revue ges. Hydrobiologia. 50: 421-463.

[12] Xiong, J.; Liu, Y.; Lin, X.; Zhang, H.; Zeng, J.; Hou, J.; Yang, Y.; Yao, T., 2012. "Geographic distance and $\mathrm{pH}$ drive bacterial distribution in alkaline lake sediments across Tibetan Plateau". Environmental Microbiology: no. 10, 1462-2920. 